\title{
Empathic decline and training in nursing students
}

\author{
Declinación empática y formación de estudiantes de enfermería \\ Declínio de empatia e formação de estudantes de enfermagem
}

How to cite this article:

Díaz-Narváez VP, Calzadilla-Núñez A, López-Orellana P, Utsman-Abarca R, Alonso-Palacio LM. Empathic decline and training in nursing students. Rev Esc Enferm USP. 2020;54:e03619. doi: https://doi.org/10.1590/S1980-220X2019006803619

\author{
Víctor P. Díaz-Narváez ${ }^{1}$ \\ Aracelis Calzadilla-Núñez ${ }^{2,3}$ \\ Paulina López-Orellana ${ }^{4}$ \\ Robert Utsman-Abarca ${ }^{5}$ \\ Luz Marina Alonso-Palacio ${ }^{6}$ \\ ${ }^{1}$ Universidad de Andres Bello, Facultad \\ de Odontología, Departamento de \\ Investigaciones, Santiago, Chile. \\ ${ }^{2}$ Universidad Bernardo OHiggins, \\ Facultad de Salud, Santiago, Chile. \\ ${ }^{3}$ Universidad Autónoma de Chile, Facultad \\ de Ciencias de la Salud, Santiago, Chile. \\ ${ }^{4}$ Universidad de Valparaíso, Faculdad \\ de Medicina, Escuela de Obstetricia \\ y Puericultura, Valparaíso, Chile. \\ ${ }^{5}$ Universidad Latinoamericana de \\ Ciencia y Tecnología, Departamento de \\ Investigaciones, San José, Costa Rica. \\ ${ }^{6}$ Universidad del Norte, División de \\ Ciencias de la Salud, Departamento de \\ Salud Pública. Barranquilla, Colombia.
}

\begin{abstract}
Objective: The objective of this article is to examine whether the levels of empathy fit the concept of empathic decline. Method: This was a non-experimental and crosssectional study. Two populations of nursing students in two nursing programs were studied: Universidad San Sebastián (Santiago, Chile) and Universidad Mayor (Temuco, Chile). The original data on empathy, assessed by the Jefferson Scale of Empathy, were combined into a single data base. They were then analyzed by means of normality tests and homoscedasticity, Cronbach's alpha, analysis of variance; the standard deviation of the dependent outcome measure (Sy.x) and the coefficient of determination $\left(\mathrm{R}^{2}\right)$ were estimated. Results: The sample sizes from the two programs were 479 and 277, respectively. It was found that the distributions of the averages over the course of study for empathy (and its components) were constant, and in some cases increased. Conclusion: It was found that the distribution of the means of empathy in the nursing students analyzed did not conform to the classical empathic decline observed in other studies. Therefore, it is inferred that the traditional factors identified as causes of empathic erosion were not operating in the same way in the studied context.
\end{abstract}

\section{DESCRIPTORS}

Students, Nursing; Empathy; Nurse-Patient Relations; Nurse's Role. 


\section{INTRODUCTION}

It is known that empathy is an attribute that all nursing professionals must have for positive overall outcomes with patients ${ }^{(1-2)}$. The benefits produced by this construct in the process of patient care are well established, as is how patients respond positively when cared for with empathy, especially when being cared for by geriatricians and pediatricians ${ }^{(2)}$. The empathy developed by nursing professionals depends (in part) on the empathic training process during their years as students ${ }^{(3)}$, and their time in universities is the last opportunity to develop it. Universities must take responsibility for this training as part of the development of desirable attributes and qualities, and create the necessary conditions for its development and consolidation, because empathy is one of the competencies considered to be most important in the nursing profession ${ }^{(4)}$.

The instrument most commonly used to measure empathy in the area of health care is the Jefferson Scale of Empathy (JSE) (Version-S) ${ }^{(5)}$, which has a multidimensional structure: Compassionate Care (CC), Perspective Taking $(\mathrm{PT})$ and Ability to Understand Others (AUO) $)^{(5)}$. In Latin America, there are few studies of empathic behavior over the years of nursing courses among students ${ }^{(6-8)}$. There is a natural tendency to carry out studies that involve measurement of levels of empathy in nursing students or focus on psychological relationships between nurses and patients, and how empathy develops or must develop in that context. However, there are no detailed studies in relation to: a) how empathy and its components behave in the process of university education; and b) the process of empathic decline that students are assumed to experience. Such knowledge is of great significance when focusing on empathic interventions.

The aim of this study was to verify the existence of possible differences between levels of empathy (and its components) over the course of study in the students analyzed with respect to the classical empathic decline observed in other studies. Hypothesis: Levels of empathy (and its components) in the nursing students examined will show an increase between the first and third year and a decrease from fourth year.

\section{METHOD}

\section{Study DESIGN}

An exploratory and comparative study of two cohorts.

\section{Study SeTting}

The sample consisted of the students in the Nursing Programs of the Universidad San Sebastián (USS) (Santiago, Chile) and Universidad Mayor (UM) (Temuco, Chile).

\section{Population}

The sample sizes were as follows: USS: $\mathrm{n}=479 ; \mathrm{N}=$ 740/64.7\%; and UM: $\mathrm{n}=277 ; \mathrm{N}=403 / 68.7 \%$. All students who attended classes on the day of the application of the instrument were included, without restriction. Students who were absent were not evaluated later, in order not to contaminate the answers.

\section{Data collection}

The data were collected in July $2013^{(3)}$ and October 2016. All students who attended were evaluated after signing an informed consent form. The JSE was applied (Version S), which had been validated and adapted in Chile for nursing students ${ }^{(3)}$. Before being applied, the JSE was submitted to judges to verify the cultural and content validity in both universities. Application was confidential (with a neutral operator).

\section{INSTRUMENTS}

The JSE (Version S) is an instrument to measure empathy in medical students. It consists of 20 items, scored on a Likert scale ranging from one to seven points (140 points in total). It presents three dimensions associated with cognitive and emotional aspects and presents satisfactory $\alpha$-Cronbach values. This instrument has been described exhaustively in the literature and is summarized in a study by Alcorta-Garza et al. (5). The dependent variable used in the present study was the level of empathy and its components; the independent variables or factors were the nursing programs of the universities examined, the courses, gender and empathic decline.

\section{ANALYSIS AND TREATMENT OF DATA}

The original data were combined into a single data base and analyzed using normality tests (Kolmogorov-Smirnov, for data greater than or equal to 50) and homoscedasticity (Levene). The internal reliability: was calculated using Cronbach's alpha and the intraclass correlation coefficient. Regression testing was done to study the mean values for each course of study (school year). An analysis of variance (ANOVA) was done sequentially. The sequential ANOVA was used because it provides information on the form of regression of the data; therefore, this test determines the form of association a posteriori and allows selection of the regression curve that best fits the data. As a consequence, use of the sequential ANOVA is the necessary and sufficient test to determine the form of association in the regression equation obtained. The standard deviation of the dependent outcome measure (Sy.x) and the coefficient of determination $\left(\mathrm{R}^{2}\right)$ were estimated. The type of curve was calculated using a regression test. Data were processed using SPSS $23.0{ }^{\circledR}$ and Minitab ${ }^{\circledR} 17.0$ statistical software. The significance level was set at $\alpha \leq 0.05$.

\section{ETHICAL ASPECTS}

The study was approved by the ethics committees of both Universidad San Sebastián (Santiago, Chile: IF No. 2915-02) and Universidad Mayor ${ }^{(3)}$. The application of the instrument did not imply any psychological or physical risk to the students evaluated. The approval included the text of the informed consent, which had to be read and signed before responding to the applied instrument. 


\section{RESULTS}

The distribution of the participants by university and gender and the total observed was: UM (Temuco): 81.59\% were women $(\mathrm{n}=226)$ and $18.41 \%$ were men $(\mathrm{n}=51)$; USS (Santiago): $65.23 \%$ were women $(n=349)$ and $34.77 \%$ were men $(\mathrm{n}=186)$. For the total sample, $70.81 \%$ were women $(\mathrm{n}=575)$ and $29.19 \%$ were men $(\mathrm{n}=237)$. In relation to age in general, the mean (M) and standard deviation (SD) were: UM (Temuco): $\mathrm{M}=23.3$; $\mathrm{SD}=3.21$; USS (Santiago): $\mathrm{M}=21.8 ; \mathrm{SD}=1.53$. For the total sample, this was: $\mathrm{M}=22.55 ; \mathrm{SD}=2.67$.

The normality tests and homoscedasticity were not significant $(p>0.05)$ and it was inferred that the data had a normal distribution and equality of variance between the groups compared. As a result, the relevant parametric statistical tests could be used. Cronbach's alpha was without typifying $=0.81$ and typified $=0.83$. The total Cronbach's alpha, if an element (question) was eliminated, fluctuated between $[0.79 ; 0.82]$. The intraclass correlation coefficient was 0.812 ; confidence interval (IC) $[0.79 ; 0.83](\mathrm{F}=5.31, \mathrm{p}=0.001)$

Table 1 shows that, in relation to the shape of the regression, in all cases the equations were of a cubic type (with the sole exception of women of the UM in the component AUO, which was quadratic). The Sy.x values were relatively small, with relatively high $\mathrm{R}^{2}$ values, showing that the observed models were an adequate fit with the values of the means across the course of the years.

Table 1 - Results of estimation of empathy means and standard deviation (of each component) by gender, course and estimation of the type of equation, standard deviation of the dependent variable (E, CC, TP and AUO): Sy.x and value of the determination coefficient: $R^{2}(\%)$.

\begin{tabular}{|c|c|c|c|c|c|c|c|}
\hline & & & $\mathbf{E}$ & $\mathrm{CC}$ & PT & AUO & \\
\hline University & C & G & $\mathrm{M} \pm \mathrm{SD}$ & $\mathrm{M} \pm \mathrm{SD}$ & $\mathrm{M} \pm \mathrm{SD}$ & $\mathrm{M} \pm \mathrm{SD}$ & n (\%) \\
\hline UM & First & $\mathrm{F}$ & $111.37 \pm 15.01$ & $36.63 \pm 9.47$ & $63.22 \pm 5.58$ & $11.52 \pm 4.04$ & $46(20.2)$ \\
\hline \multirow[t]{17}{*}{ (Temuco) } & & M & $111.94 \pm 13.76$ & $38.00 \pm 8.56$ & $64.33 \pm 5.20$ & $9.61 \pm 3.66$ & $18(6.4)$ \\
\hline & & Total & $111.53 \pm 14.56$ & $37.02 \pm 9.17$ & $63.53 \pm 5.46$ & $10.98 \pm 4.00$ & $64(23.1)$ \\
\hline & Second & $\mathrm{F}$ & $119.81 \pm 11.54$ & $43.51 \pm 6.39$ & $65.14 \pm 5.46$ & $11.16 \pm 3.31$ & $43(15.5)$ \\
\hline & & $M$ & $118.50 \pm 15.39$ & $43.44 \pm 7.89$ & $64.19 \pm 6.54$ & $10.88 \pm 3.84$ & $16(5.7)$ \\
\hline & & Total & $119.46 \pm 12.57$ & $43.49 \pm 6.76$ & $64.88 \pm 5.73$ & $11.08 \pm 3.43$ & $59(21.2)$ \\
\hline & Third & $F$ & $123.59 \pm 8.21$ & $45.80 \pm 3.62$ & $65.35 \pm 4.25$ & $12.44 \pm 3.80$ & $66(23.8)$ \\
\hline & & M & $125.86 \pm 4.59$ & $47.43 \pm 2.63$ & $66.43 \pm 2.29$ & $12.00 \pm 2.16$ & $7(2.5)$ \\
\hline & & Total & $123.81 \pm 7.94$ & $45.96 \pm 3.56$ & $65.45 \pm 4.11$ & $12.40 \pm 3.66$ & $73(26.4)$ \\
\hline & Fourth & $F$ & $118.53 \pm 14.01$ & $42.77 \pm 7.46$ & $62.77 \pm 7.49$ & $13.00 \pm 3.61$ & 47 (16.9) \\
\hline & & M & $112.00 \pm 5.33$ & $41.40 \pm 4.39$ & $60.40 \pm 6.87$ & $10.20 \pm 2.38$ & $5(1.8)$ \\
\hline & & Total & $117.90 \pm 13.53$ & $42.63 \pm 7.21$ & $62.54 \pm 7.41$ & $12.73 \pm 3.59$ & $52(18.7)$ \\
\hline & Fifth & $\mathrm{F}$ & $123.08 \pm 12.21$ & $44.87 \pm 4.79$ & $63.79 \pm 8.98$ & $14.42 \pm 3.83$ & $24(8.6)$ \\
\hline & & M & $123.40 \pm 9.76$ & $46.20 \pm 2.68$ & $64.20 \pm 6.65$ & $13.00 \pm 3.39$ & $5(1.8)$ \\
\hline & & Total & $123.14 \pm 11.66$ & $45.10 \pm 4.49$ & $63.86 \pm 8.52$ & $14.17 \pm 3.74$ & $29(14.5)$ \\
\hline & Total & $F$ & $119.28 \pm 12.84$ & $42.77 \pm 7.36$ & $64.17 \pm 6.16$ & $12.34 \pm 3.83$ & $226(81.6)$ \\
\hline & & M & $117.04 \pm 13.25$ & $42.14 \pm 7.68$ & $64.18 \pm 5.67$ & $10.73 \pm 3.49$ & $51(18.4)$ \\
\hline & & Total & $118.87 \pm 12.92$ & $42.65 \pm 7.41$ & $64.17 \pm 6.06$ & $12.04 \pm 3.81$ & $277(100)$ \\
\hline USS & First & $F$ & $106.54 \pm 17.19$ & $35.72 \pm 8.56$ & $58.15 \pm 9.63$ & $12.68 \pm 3.47$ & $68(12.7)$ \\
\hline \multirow[t]{17}{*}{ (Santiago) } & & M & $108.39 \pm 13.29$ & $37.41 \pm 6.84$ & $58.85 \pm 7.87$ & $12.12 \pm 3.26$ & $41(7.7)$ \\
\hline & & Total & $107.24 \pm 15.80$ & $36.36 \pm 7.97$ & $58.41 \pm 8.98$ & $12.47 \pm 3.39$ & $109(20.4)$ \\
\hline & Second & $F$ & $109.18 \pm 12.10$ & $36.69 \pm 7.32$ & $61.57 \pm 5.72$ & $10.92 \pm 3.57$ & $74(13.8)$ \\
\hline & & M & $104.45 \pm 15.14$ & $33.89 \pm 8.17$ & $58.84 \pm 7.47$ & $11.73 \pm 3.20$ & $44(8.3)$ \\
\hline & & Total & $107.42 \pm 13.44$ & $35.64 \pm 7.98$ & $60.55 \pm 6.53$ & $11.22 \pm 3.45$ & $118(22.1)$ \\
\hline & Third & $F$ & $115.39 \pm 12.62$ & $40.91 \pm 7.81$ & $62.59 \pm 6.34$ & $11.89 \pm 3.59$ & $79(14.7)$ \\
\hline & & M & $109.90 \pm 13.91$ & $39.98 \pm 6.45$ & $58.68 \pm 7.53$ & $11.25 \pm 3.24$ & $40(7.5)$ \\
\hline & & Total & $113.55 \pm 13.27$ & $40.60 \pm 7.36$ & $61.28 \pm 6.99$ & $11.67 \pm 3.48$ & $119(22.2)$ \\
\hline & Fourth & $F$ & $117.34 \pm 10.06$ & $43.80 \pm 4.23$ & $60.38 \pm 6.51$ & $13.16 \pm 3.83$ & $56(10.5)$ \\
\hline & & M & $110.80 \pm 12.86$ & $40.93 \pm 6.28$ & $58.97 \pm 6.71$ & $10.90 \pm 3.18$ & $30(5.6)$ \\
\hline & & Total & $115.06 \pm 11.47$ & $42.80 \pm 5.19$ & $59.88 \pm 6.58$ & $12.37 \pm 3.47$ & $86(16.1)$ \\
\hline & Fifth & $F$ & $114.67 \pm 13.46$ & $42.22 \pm 5.99$ & $60.24 \pm 7.26$ & $12.21 \pm 3.81$ & $72(13.4)$ \\
\hline & & M & $115.29 \pm 10.47$ & $43.13 \pm 4.15$ & $60.35 \pm 6.23$ & $11.81 \pm 3.85$ & $31(5,7)$ \\
\hline & & Total & $114.85 \pm 12.59$ & $42.50 \pm 5.49$ & $60.27 \pm 6.93$ & $12.09 \pm 3.81$ & $103(19.2)$ \\
\hline & Total & $F$ & $112.51 \pm 13.86$ & $39.74 \pm 7.74$ & $60.67 \pm 7.31$ & $12.11 \pm 3.64$ & $349(65.3)$ \\
\hline & & $M$ & $109.32 \pm 13.71$ & $38.65 \pm 7.33$ & $59.08 \pm 7.21$ & $11.59 \pm 3.32$ & $186(34.7)$ \\
\hline & & Total & $111.40 \pm 13.88$ & $39.36 \pm 7.61$ & $60.12 \pm 7.31$ & $11.93 \pm 3.54$ & 535 (100) \\
\hline
\end{tabular}




\begin{tabular}{|c|c|c|c|c|}
\hline University & Gender & Regression Equation & Sy.x & $\mathbf{R}^{2}$ \\
\hline \multicolumn{5}{|l|}{$\mathbf{E}$} \\
\hline UM & $\mathrm{F}$ & $E=84,3+37,4 C-11.9 C^{2}+1.9 C^{3}$ & 2.72 & .92 \\
\hline UM & M & $\mathrm{E}=73.4-54.7 C-19.2 C^{2}+2.04 C^{3}$ & 8.13 & .59 \\
\hline USS & $\mathrm{F}$ & $E=109.3-7.29 C+5.08 C^{2}-0.69 C^{3}$ & .89 & .99 \\
\hline USS & M & $\mathrm{E}=118 \cdot 0-14 \cdot 7 \mathrm{C}+5 \cdot 23 \mathrm{C}^{2}-0.48 \mathrm{C}^{3}$ & 2.63 & .88 \\
\hline \multicolumn{5}{|l|}{ CC } \\
\hline UM & $\mathrm{F}$ & $C C=16.9+27.1 C-8.35 C^{2}+0.8 C^{3}$ & 1.44 & .97 \\
\hline UM & M & $C C=16,1+30.4 C-10.02 C^{2}+1.02 C^{3}$ & 3.52 & .78 \\
\hline USS & $\mathrm{F}$ & $C C=47.2-15.9 C+6.9 C^{2}-0.79 C^{3}$ & .38 & .99 \\
\hline USS & M & $C C=48 \cdot 4-17.3 C+6.7 C^{2}-0.69 C^{3}$ & 2.54 & .87 \\
\hline \multicolumn{5}{|l|}{ PT } \\
\hline UM & $\mathrm{F}$ & $\mathrm{TPP}=54.7+12.3 \mathrm{C}-4.3 \mathrm{C}^{2}+0.44 \mathrm{C}^{3}$ & .89 & .85 \\
\hline UM & M & $\mathrm{TPP}=54.5+14.4 \mathrm{C}+5.6 \mathrm{C}^{2}+0.62 \mathrm{C}^{3}$ & 3.42 & .38 \\
\hline USS & $\mathrm{F}$ & $\mathrm{TPP}=48.3+13.5 \mathrm{C}-4.09 \mathrm{C}^{2}+0.37 \mathrm{C}^{3}$ & .73 & .95 \\
\hline USS & M & $\mathrm{TPP}=58.1+14.0 \mathrm{C}-0.69 \mathrm{C}^{2}+0.103 \mathrm{C}^{3}$ & .01 & .99 \\
\hline \multicolumn{5}{|l|}{ AUO } \\
\hline UM & $\mathrm{F}$ & $A \cup O=11.6-0.45 C+0.203 C^{2}$ & .37 & .96 \\
\hline UM & M & $\mathrm{A} \cup \mathrm{O}=2.73+9.9 \mathrm{C}-3.6 \mathrm{C}^{2}+0.39 \mathrm{C}^{3}$ & 1.24 & .79 \\
\hline USS & $\mathrm{F}$ & $A \cup O=20.03-11.03 C+4.03 C^{2}-0.43 C^{3}$ & .01 & .99 \\
\hline USS & M & $A \cup O=11.5+1.34 C-0.82 C^{2}+0.11 C^{3}$ & .11 & .98 \\
\hline
\end{tabular}

C: Course. G: Gender. F: Female; M: Male. E: Empathy. CC: Compassionate Care. PT: Perspective Taking. AUO: Ability to Understand Another. UM: Universidad Mayor (Temuco). USS: Universidad San Sebastián (Santiago). n: Sample Size. M: Median. SD: Standard deviation; Type of equation: Cubic in all cases, with exception of female gender (AUO), which was quadratic; $\mathbf{R}^{2}$ : Coefficient of determination.

Figure 1 shows that the levels of empathy in women of the UM (1a) were "flat" (considering that this concept reflects low fluctuation of empathy and its components throughout the courses); however, in the women of the USS, (1c) a slope of growth was observed with a decline in the fifth year that did not reach the values of the first year. In men of both universities $(1 \mathrm{~b}$ and $1 \mathrm{~d})$, the behavior of the means throughout the course of the years was similar, without a decline.
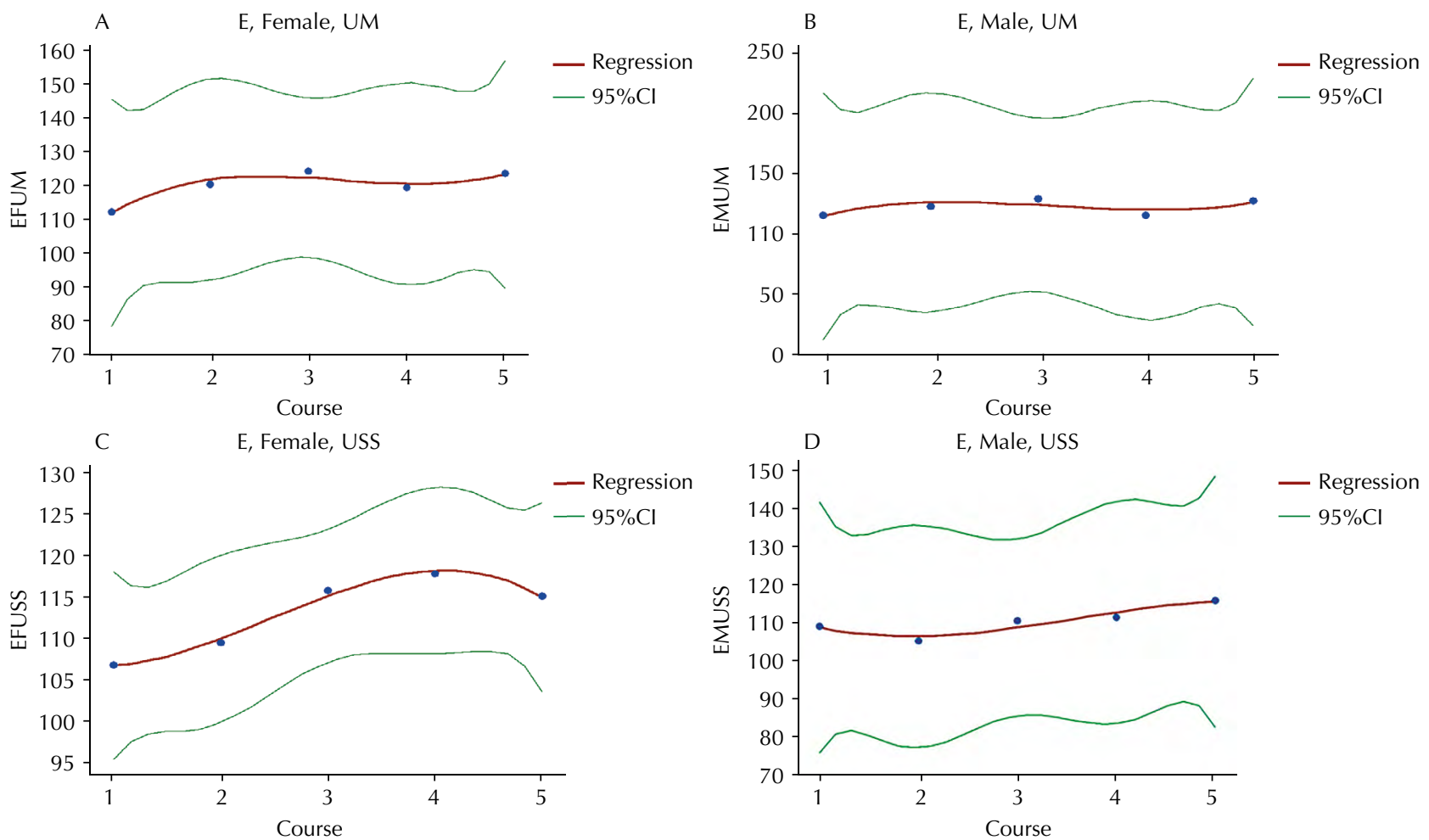

Figure 1 - Results of the estimation of the regression curves for the components of empathy by gender and course in the Universidad Mayor (UM) (Temuco) and Universidad San Sebastián (USS) (Santiago). 
Figure 2 shows that the behavior of the CC component of empathy in women ( $2 \mathrm{a}$ and $2 \mathrm{c})$ and men $(2 \mathrm{~b}$ and $2 \mathrm{~d})$ of the UM and USS was very similar to overall levels of empathy
(Figure 1), and no declension was found, with the exception of the women of the USS in the fifth year, but with values higher than those observed in the first year for this group.
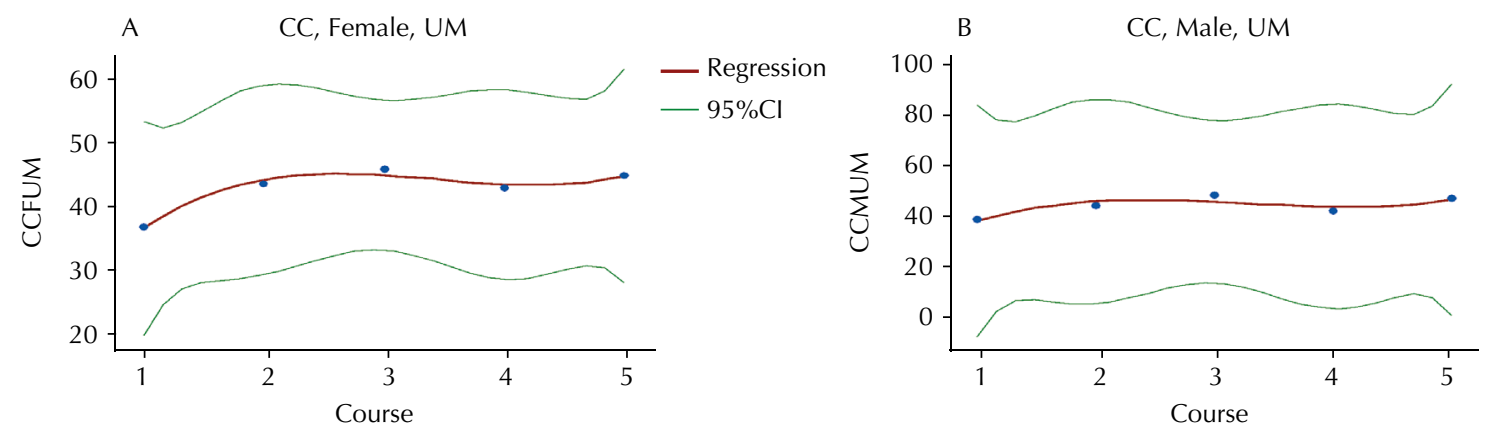

- Regression
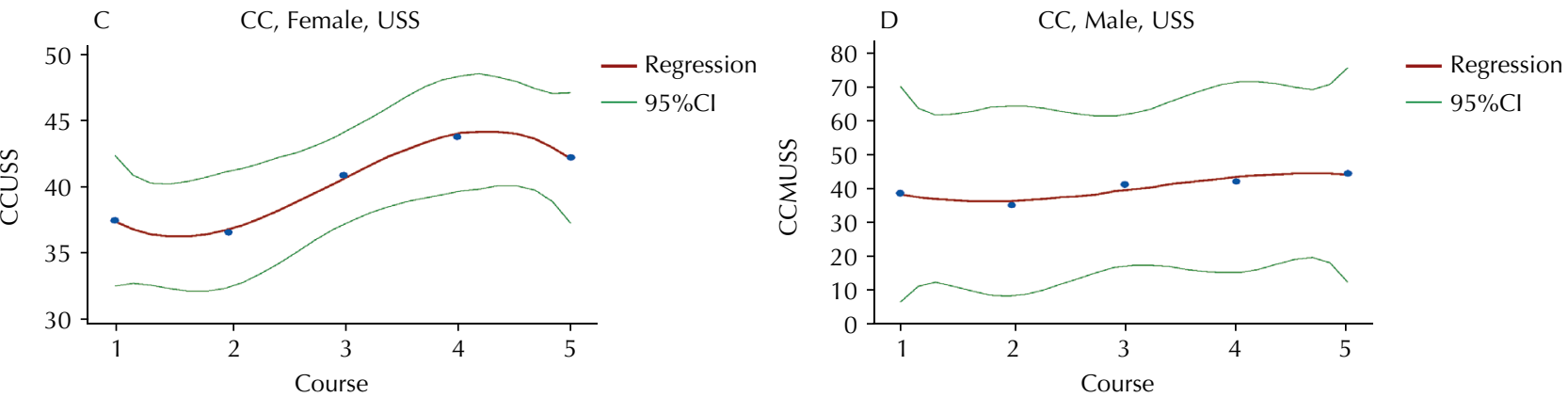

Figure 2 - Results of the estimation of regression curves in the component of Compassionate Care of empathy by gender and course in the Universidad Mayor (UM) (Temuco) and Universidad San Sebastián (USS) (Santiago).

Figure 3 shows that the behaviors of the PT component in the women of the UM (3a) and USS (3c) were similar, with fluctuations of the values of the means within a small range for PT; therefore, it could be considered stable (without declination). The men of the USS showed different results; in the men from the UM, the values of the means (3b) behaved in a "stable" way throughout the course of the years. However, there is was a remarkable increase for men from the USS (3d) in the fifth year, which occurred in a very small range of values.
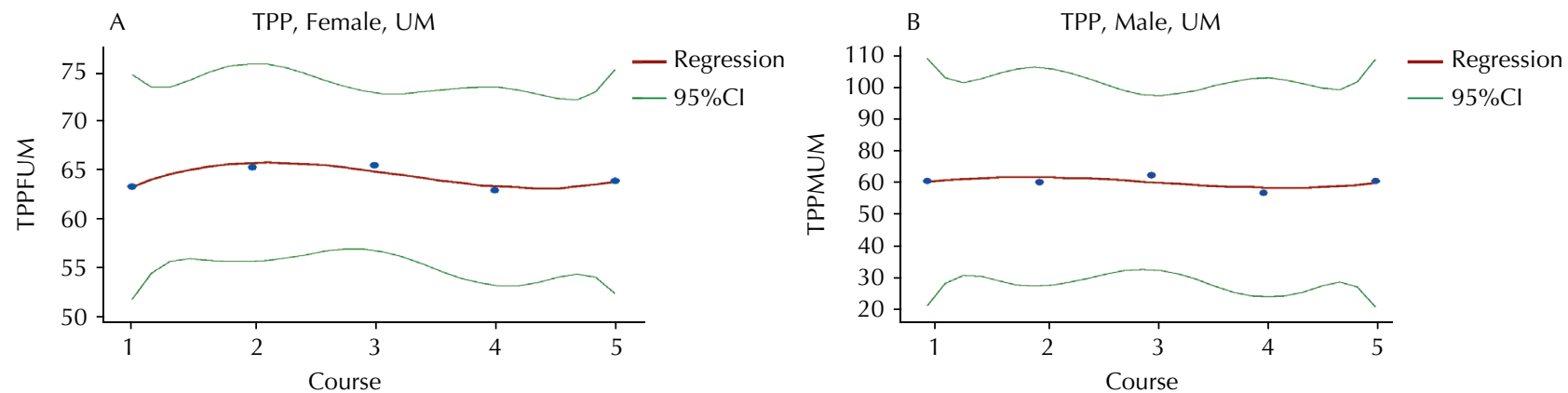

C

TPP, Female, USS

D

TPP, Male, USS
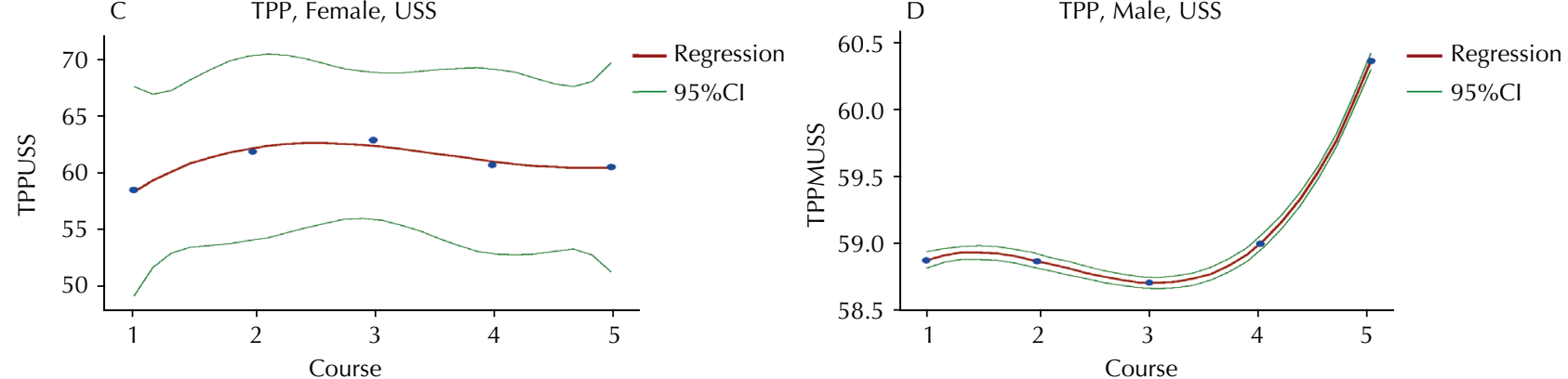

Figure 3 - Results of the estimation of regression curves in the component of Perspective Taking of empathy by gender and course in the Universidad Mayor (UM) (Temuco) and Universidad San Sebastián (USS) (Santiago). 
Finally, Figure 4 shows the behavior of the AUO component. In women from the UM, there were small, constant increases in the means of AUO throughout the course of the years (4a), while the women from the USS showed small decreases and increases over the course of years, but as in the previous cases, these were fluctuations of very small values (4c). It was also found that in men from the UM, the averages behaved in a stable manner ( $4 \mathrm{~b}$ and $4 \mathrm{~d}$ ), although the men from the USS showed an increase in the fifth year, with the same characteristics already indicated above.
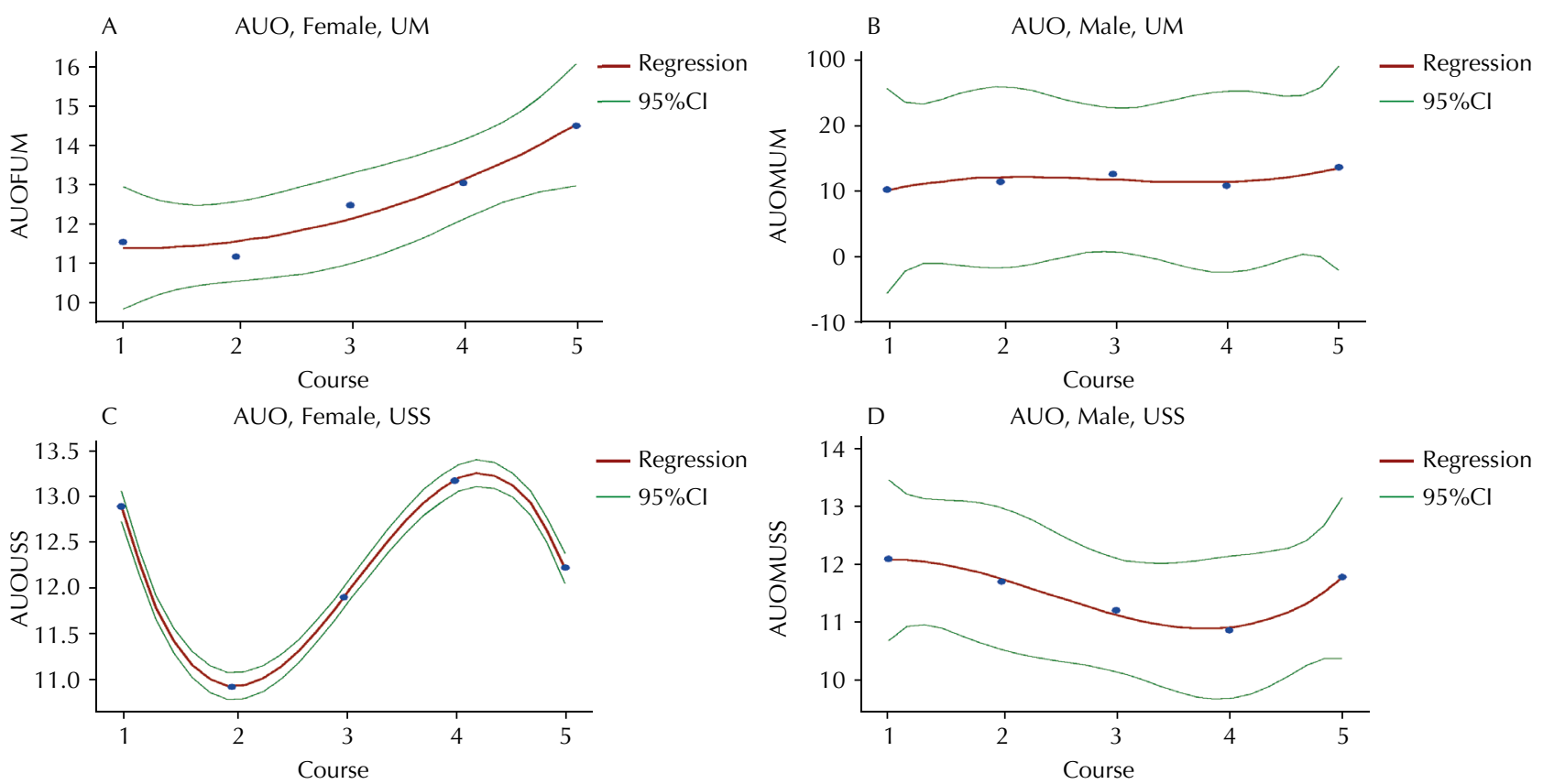

Figure 4 - Results of the estimation of regression curves in the component of Ability to Understand Another (AUO) of empathy by gender and course at the Universidad Mayor (UM) (Temuco) and Universidad San Sebastián (USS) (Santiago).

\section{DISCUSSION}

The hypothesis of the present work was that the nursing students of the analyzed universities would present a different distribution of the means for empathy (and its components) over the years in relation to a distribution characterized by empathic decline. As a consequence, the aim of this study was to verify that levels of empathy throughout the course of years was different from the distribution of a classical empathic decline, including the components of empathy. It is known that empathy has components that are affective-emotional $(\mathrm{CC})$ and cognitive $(\mathrm{PT} \text { and } \mathrm{AUO})^{(5)}$. Some authors have suggested that the $\mathrm{CC}$ component is difficult to teach, and that it is a product of, or is related to (or both), the moral formation of subjects, family environments, and religiosity (in some cases), among other factors ${ }^{(5-10)}$, while the cognitive components (given their nature) are susceptible to being taught ${ }^{(5-6)}$. On the other hand ${ }^{(7-8)}$, it should be noted that the presence of empathic decline is based on the findings of studies of means of levels of empathy in medical students ${ }^{(11)}$. This process is characterized because empathy increases persistently from the first to third years and then declines in the same way. The decrease in empathy is due to a more internal process, called "empathic erosion", which means that levels of empathy were "eroded" due to an adjustment of students to contact and confrontation with patients in the clinical area. The factors that influence this adjustment have been described, including some well-founded hypotheses about the way they impact empathy ${ }^{(12-17)}$.

However, some authors have found evidence that the empathic decline in students does not always occur; this has been found in various health careers ${ }^{(3,9-10,18-20)}$. It has been suggested ${ }^{(21)}$ that empathic decline is a particular case of various behaviors of means of empathy throughout courses or years of study, and that there is variability in this behavior. The results of the present study contribute to those based on more empirical evidence that tends to support the approaches of the authors mentioned above ${ }^{(21)}$ and emphasizes that the decline ${ }^{(14-15)}$ constitutes a scientific fact, but not a general one, but rather a particular one. The implications derived from observation of the existence of variability in the empathic response in nursing students and other health professions throughout the years of studies (courses) could serve as an effective methodological guide for the realization of pedagogical interventions or efficient, planned educational strategies to influence a possible increase in empathy among these students.

If the model of empathic decline ${ }^{(15)}$ were universally shown, the pedagogical response would be clear and concrete, in terms of creating a pool of specific methodologies to face the decline and nullify the causes that produce it. But, 
even if that were true in any case, it would be very complex and would require, before each intervention, studies of specific causes and the operation of their contribution to the process of decline. However, if it is indeed a particular case, and the evidence is consistent in this sense $e^{(18-21)}$, then it is necessary to carry out exhaustive study of levels of empathy before developing any intervention processes, considering, in all cases, not only the study of empathy as a monolithic construct, but also of each of its components. The "simple fact" is that empathy is a dialectical synthesis of its three components. Therefore, the expression of empathy is nothing more than the very expression of the particular correlation that can occur between these components which, in turn, in their "determination", operate on them, in addition to intrinsic factors, as well as extrinsic factors ${ }^{(9-13)}$. These circumstances make it necessary to be stricter in decisions to carry out intervention That is because detailed examination of the components and the causes that produce certain behaviors in each component will constitute a specific guide for the empathic-educational intervention in the sense of the actions that could be derived from this intervention. This would include modification of the curriculum based on the findings, preparation of teachers for the implementation of the new curriculum, positive empowerment of the hidden curriculum, inclusion of certain active teaching-learning methods, and the form and the time at which these methods are included in the curriculum, among other actions. All of this would be materialized in particular actions applicable to specific contexts that are not valid for other contexts. It is also necessary not to forget an essential issue: Any intervention must be theoretically conceived to guarantee permanent changes in levels of empathy, not just circumstantial changes ${ }^{(21)}$.

It is difficult to explain the differences between women of the two universities studied in relation to levels of empathy and the relative "similarity" of those levels among the men of both universities (regardless of whether or not the estimated levels of empathy estimated were equal between them). However, a general characteristic of the findings was that the classical process of decline did not manifest (with the exception of women from the USS in the fifth year). As a consequence, certain questions must be answered before an explanation for this observation can be inferred: a) What factors influence the absence of a decline; and b) What factors are absent or do not operate properly that induce stable behavior between the courses and do not induce an increase in empathy?

Analysis of the behavior of the CC component showed similarity to that of empathy as a construct. It is attractive, then, to attribute the behavior of empathy through this similarity. That is, the changes in the levels of empathy of the women from the USS could be explained by the changes that occurred in one of its components: CC. This possible explanation is reasonable, but it does not fully explain the observations. As indicated above, the $\mathrm{CC}$ component is emotional-affective and can therefore be stimulated by spirituality ${ }^{(22-23)}$, reasoning and pro-social attitudes ${ }^{(24)}$, morality $^{(25)}$, altruism ${ }^{(26)}$, assuming universal values and parental support $^{(27)}$, and culture ${ }^{(28)}$, among other factors. Therefore, all the above-mentioned aspects should be studied to explain two "subtle" questions: a) How have these factors worked on women from the USS; and b) How have they operated in women from the UM, and men in both universities?

Regardless of the answers to these questions, all these aspects are difficult to teach once students enter the university, because these components respond to the history of the ontogeny of subjects ${ }^{(29)}$, that is, how intrinsic and extrinsic factors interact specifically on subjects from birth until they reach the university. Therefore, a university receives students with a structured CC component and with few possibilities of being stimulated in the positive direction of its development ${ }^{(21)}$. However, if subjects arrive at the university with high development of this component, increases in its levels may be due to its natural structural base in reaction to positive feedback from suffering of patients, or the university may have a formal or hidden curriculum (or both) that provides positive stimulation of this component. Then, as a matter of principle, the university has an opportunity (and a duty) to create the right conditions to stimulate this component, which leads directly to a need (obligation) to assume integral formation of students.

The PT component is associated with the ability of individuals to "stand in the patient's shoes" and, in this way, to understand patients better and contribute to changes in their attitudes, as well as being able to predict and understand their emotions, motivations, preferences and actions. As a consequence, this component is associated with metacognition and is of special relevance to understanding the mental state of patients. The observed results showed that there was no decline, and this component remained stable throughout the courses ( $3 a, 3 b$ and $3 c$ ), the exception being men at the USS, where there was a positive change in levels of empathy, precisely in the courses corresponding to the clinical area. However, the range of values of the levels indicated was small and this change was not quantitatively remarkable. Since this component can be taught, these results could account for a structural failure in the curriculum of both universities in relation to the teaching of this component in all courses, but at the same time, these results show that students did not decrease their levels, that is, they were not affected by empathic erosion. From an objective point of view, this situation could be an opportunity for both universities. Knowledge of the specific causes for the lack of a decline and, at the same time, reasons why there was not an increase over the years of study constitutes important information and a specific result for levels of empathy in the students examined.

The AUO component is also associated with the cognitive structure of empathy. The results of the present study showed that, in general, the values of the means were stable between the measurements of the different academic years, given that the range in which they moved was reduced. Nevertheless, the results observed in women from the UM are noteworthy: Not only did no decline appear, but there was also a systematic, but slight, increase in the means of the AUO component of empathy. This slight increase (as 
well as the stability shown in empathy and in each component), once explained, will constitute a basis for a possible intervention.

The combination of these results implies that in order to increase levels of empathy among nursing students, factors that maintain the stability of levels of empathy between courses must be taken into consideration. This knowledge could allow action to reduce the effect of factors that participate in the erosion of levels of empathy and, at the same time, reinforce the factors that contribute to the increase of empathy in future nurse practitioners ${ }^{(10,16-17,21)}$. This knowledge could also be useful in other healthcare professions in which empathy is a main competency for establishing relationships with persons receiving care and contributing to solutions to the new challenges that are faced by the nursing profession ${ }^{(30)}$.

The main limitation of this study is that the sample size did not cover the total population analyzed. However, the results can be considered as marking trends coming from a majority of the subjects in each population.

\section{CONCLUSION}

It was found that the distribution of the means for levels of empathy (and those of its components) in the nursing students analyzed do not conform to classical empathic decline. Therefore, it is inferred that the traditional factors that are identified as causes of empathic erosion are not operating in the same way in the context of study. Causes for the stability of the values of the means produced cannot be explained within the scope of the present study. However, it shows that an empathic-educational intervention that aims to increase levels of empathy over the course of the curriculum should be preceded by knowledge of the factors that are influencing stagnation of, or decreases in, empathy.

\section{RESUMEN}

Objetivo: El objetivo del artículo es analizar si los niveles de empatía se ajustan al concepto de declinación empática. Método: Estudio no experimental y transversal. Fueron estudiadas dos poblaciones de estudiantes de enfermería de dos facultades de enfermería: Universidad San Sebastián (Santiago, Chile) y Universidad Mayor (Temuco, Chile). Los datos originales de empatía, evaluados por el Jefferson Scale of Empathy, fueron reunidos en un único grupo y analizados con pruebas de normalidad y homocedasticidad, alfa de Cronbach, análisis de varianza; también fueron estimados el desvío estándar de la medida de resultado dependiente (Sy.x) y el coeficiente de determinación (R2). Resultados: Las muestras de las dos facultades constaron de 479 y 277 participantes, respectivamente. Se comprobó que las distribuciones de medias del curso de estudio para empatía (y sus componentes) fueron constantes, y en algunos casos aumentaron. Conclusión: Se determinó que la distribución de medias de empatía en los estudiantes de enfermería analizados no se ajusta a la disminución empática clásica observada en otros estudios, infiriéndose que los factores tradicionales considerados como causas de la erosión empática no operan de la misma manera en el contexto estudiado.

\section{DESCRIPTORES}

Estudiantes de Enfermería; Empatía; Relaciones Enfermero-Paciente; Rol de la Enfermera.

\section{RESUMO}

Objetivo: O objetivo do presente artigo é investigar se os níveis de empatia são consistentes com o conceito de declínio de empatia. Método: Um estudo não-experimental e transversal foi conduzido com duas populações de alunos de enfermagem de dois programas de enfermagem distintos, da Universidad San Sebastián (Santiago, Chile) e da Universidad Mayor (Temuco, Chile). Os dados originais sobre empatia, avaliados pela Jefferson Scale of Empathy, e reunidos em um único banco de dados. Os dados foram então analisados através de testes de normalidade e homocedasticidade, Cronbach's alpha e análise de variância. Foram calculados o desvio padrão da variável dependente (Sy.x) e o coeficiente de determinação $\left(\mathrm{R}^{2}\right)$. Resultados: As amostras dos dois programas tiveram 479 e 277 participantes, respectivamente. As distribuições das médias de empatia (e seus componentes) ao longo do curso foram constantes, com um aumento em alguns casos. Conclusão: A distribuição das médias de empatia nos alunos de enfermagem estudados não foi consistente com o declínio clássico de empatia observado em outros estudos. Sendo assim, os dados indicam que os fatores tradicionais identificados como causas de erosão empática não funcionam da mesma forma no contexto avaliado.

\section{DESCRITORES}

Estudantes de Enfermagem; Empatia; Relações Enfermeiro-Paciente; Papel do Profissional de Enfermagem.

\section{REFERENCES}

1. Dal Santo L, Pohl S, Saiani L, Battistelli A. Empathy in the emotional interactions with patients. Is it positive for nurses too? J Nurs Educ Pract. 2014;4(2):74-80. DOI: http://doi.org/10.5430/jnep.v4n2p74

2. Coban Gl, Yurdagul G. The relationship between cancer patients' perception of nursing care and nursing attitudes towards nursing profession. Asia Pac J Oncol Nurs. 2014;1(1):16-21. DOI: 10.4103/2347-5625.135816

3. Martí Nogueram JJ, Martí-Vilarb M, Almerich G. Responsabilidad social universitaria: influencia de valores y empatía en la autoatribución de comportamientos socialmente responsables. Rev Latinoam Psicol. 2014;46(3):160-8.

4. Terezam R, Reis-Queiroz J, Hoga Luiza A. The importance of empathy in health and nursing care. Rev Bras Enferm. 2017;70(3):669-70. DOI: http://doi.org/10.1590/0034-7167-2016-0032.

5. Alcorta-Garza A, González-Guerrero, Tavitas-Herrera SE, Rodríguez-Lara FJ, Hojat M. Validación de la escala de empatía Médica de Jefferson en estudiantes de medicina mexicanos. Salud Mental. 2005;28(5):57-63.

6. Triana-Restrepo MC. La empatía en la relación enfermera-paciente. Av Enferm. 2017;35(2):121-2. DOI: http://doi.org/10.15446/av.enferm. v35n2.66941 
7. Beltrán-Salazar OA. Humanized care: relationship of familiarity and affectivity. Invest Educ Enferm. 2015;33(1):17-27. DOI: http://doi. org/10.17533/udea.iee.v33n1a03

8. Ramírez P, Müggenburg C. Relaciones personales entre la enfermera y el paciente. Enferm Univ. 2015;12(3):134-43. DOI: http://dx.doi. org/10.1016/j.reu.2015.07.004

9. Díaz-Narváez VP, Alonso-Palacio LM, Caro SE, Silva M, Arboleda-Castillo J, Bilbao J, et al. "Compassionate care": component of the construct empathy in medical students in Colombia and Dominican Republic. Acta Med Mediterr. 2017;33:115-21. DOI: http://doi.org/ 10.19193/0393-6384_2017_1_018

10. Calzadilla-Núñez A, Díaz-Narváez VP, Dávila Pontón Y, Aguilera-Muñoz J, Fortich-Mesa N, Aparicio-Marenco D, et al. Erosion of empathy during medical training by gender: a cross-sectional study. Arch Argent Pediatr. 2017;115(6):556-61. DOI: http://doi.org/10.5546/aap.2017.eng.556

11. Decety J, Meidenbauer K L, Cowell JM. The development of cognitive empathy and concern in preschool children: a behavioral neuroscience investigation. Dev Sci. 2018;21:e12570. DOI: http://doi.org/10.1111/desc.12570

12. Decety J, Svetlova M. Putting together phylogenetic and ontogenetic perspectives on empathy. Dev Cogn Neurosci. 2012;2(1):1-24. DOI: 10.1016/j.den.2011.05.00

13. Díaz-Narváez VP, Calzadilla-Núñez A, Alonso LM, Torres-Martínez PA, Cervantes-Mendoza M, Fajardo-Ramos E. Empathy and ontogeny: a conceptual approach. West Indian Med J. 2017;66(3). DOI: http://doi.org/10.7727.wimj/2016.344

14. Hojat M, Mangione S, Nasca TJ, Rattner S, Erdmann JB, Gonnella JS, et al. An empirical study of decline in empathy in medical school. Med Educ. 2004;38(9):934-41. DOI: 10.1111/j.1365-2929.2004.01911.x

15. Hojat M, Vergare MJ, Maxwell K, Brainard G, Herrine SK, Isenberg GA, et al. The devil is in the third year: a longitudinal study of erosion of empathy in medical school. Acad Med. 2009;84(9):1182-91. DOI: 10.1097/ACM.0b013e3181b17e55

16. Díaz-Narváez VP, Alonso-Palacio LM, Caro SE, Silva MG, Arboleda-Castillo J, Bilbao JL et al. Empathic orientation among medical students from three universities in Barranquilla, Colombia and one university in the Dominican Republic. Arch Argent Pediatr 2014;112(1):e41-e49. DOI: http://doi.org/10.1590/S0325-00752014000100008.

17. Stratta EC, Riding DM, Baker P. Ethical erosion in newly qualified doctors: perceptions of empathy decline. Int J Med Educ. $2016 ; 7: 286-92$. DOI: http://doi.org/10.5116/ijme.57b8.48e4

18. Díaz-Narváez VP, Erazo-Coronado AM, Bilbao JL, González F, Padilla M, Calzadilla-Núñez A, et al. The 'decline' of dental student empathy within the course in Latin America. Acta Med Port 2017;30(11):775-82. DOI: http://doi.org/10.20344/amp.8681

19. Roff S. Reconsidering the "decline" of medical student empathy as reported in studies using the Jefferson Scale of Physician EmpathyStudent version (JSPE-S). Med Teach. 2017;37(8):783-86. DOI: http://doi.org/10.3109/0142159X.2015.1009022

20. Ferreira-Valente A, Monteiro JS, Barbosa RM, Salgueira A, Costa P, Costa MJ. Clarifying changes in student empathy throughout medical school: a scoping review. Adv Health Sci Educ Theory Pract. 2017;22(5):1293-313. DOI: http://doi.org/10.1007/s10459-016-9704-7

21. Díaz-Narváez VP, Amezaga-Avitia C, Sarabia-Álvarez PA, Lagos-Elgueta M, Saavedra-Madrid M, Silva-Reyes P, et al. Chilean dentistry students, levels of empathy and empathic erosion: necessary evaluation before a planned intervention: levels of empathy, evaluation and intervention. Saudi Dent J. 2017;30(2):117-24. DOI: http://doi.org/10.1016/j.sdentj.2017.11.004

22. Damiano RT, DiLalla LF, Lucchetti D, Dorsey JK. Empathy in medical students is moderated by openness to spirituality. Teach Learn Med. 2017;29(2):188-95. DOI: http://doi.org/10.1080/10401334.2016.1241714

23. Souza M. The empathetic mind: the essence of human spirituality. Int J Children's Spiritual. 2014;19(1):45-54. DOI: https://doi.org/10.10 80/1364436X.2014.897221

24. Richaud de Minzi MC. Influencia del modelado de los padres sobre el desarrollo del razonamiento prosocial en los/las niños/as. Interam J Psicol. 2009;43(1):187-98.

25. Decety J, Coell JM. Empathy, justice, and moral behavior. AJOB Neurosci. 2015;6(3):3-14. DOI: http://doi.org/10.1080/21507740.2015.1047055

26. Bethlehem RAI, Allison C, van Andel EM, Coles AI, Neil K, Baron-Cohen S. Does empathy predict altruism in the wild? Soc Neurosci. 2017;12(6):743-50. DOI: http://doi.org/10.1080/17470919.2016.1249944

27. Persson BN, Kajonius PJ. Empathy and universal values explicated by the empathy-altruism hyphotesis. J Soc Psychol. 2016;156(6):610-9. DOI: http://doi.org/10.1080/00224545.2016.1152212

28. Ulloque MJ, Villalba S, Varela de Villalba T, Fantini A, Quinteros S, Díaz-Narváez VP. Empathy in medical students of Córdoba, Argentina. Arch Argent Pediatr. 2019;117(2):81-6. DOI: http://doi.org/10.5546/aap.2019.eng.81

29. Decety J, Svetlova M. Putting together phylogenetic and ontogenetic perspectives on empathy. Dev Cogn Neurosci. 2012;2(1):1-24. DOI: http://doi.org/10.1016/j.den.2011.05.003

30. Ricciardi R. The next frontier for nurses. improving quality and safety in primary care. J Nurs Care Qual. 2018;33(1):1-4. DOI: http://doi.org/10.1097/NCQ.0000000000000304 